\title{
Potential of distillery effluents for safe water through vermifiltration
}

\section{N. Kannadasan*}

Department of Zoology, Karur Velalar College of Arts and Science for Women, Karur (Tamil Nadu), India

\section{Dharshini}

Department of Home Science, Karur Velalar College of Arts and Science for Women, Karur, (Tamil Nadu), India

\section{S. Eabinezer}

Department of Botany, Karur Velalar College of Arts and Science for Women, Karur (Tamil Nadu), India

\section{Nirmala Natarajan}

PG and Research Department of Zoology, Periyar E.V.R. College, Tiruchirappalli, (Tamil Nadu), India

\section{R. Krishnamoorthy}

PG and Research Department of Zoology, Jamal Mohamed College, Tiruchirappalli (Tamil Nadu), India

\section{R. Sri Sakthi Priyadarshini}

Department of Animal Science, Bharathidasan University, Tiruchirappalli (Tamil Nadu), India

*Corresponding author. E-mail: drkannadasan87@gmail.com

\section{Abstract}

Vermifiltration of wastewater using waste eater earthworms is a newly conceived novel technology. The present study evaluated BOD, COD and TS showing significant variation in decrease by $95 \%, 90 \%$ and $80 \%$ respectively through vermifiltration of distillery effluents. The nutrient contents (TN, TP, TK, TCa and TMg) in the vermicasts had increase $(1.82 \%$ in $\mathrm{TN}, 0.24 \%$ in TP, $2.15 \%$ in $\mathrm{TK}, 2.07 \%$ in TCa and $2.86 \%$ in $\mathrm{TMg}$ ) in the range of fold than the control level. The morphology of the control and experimental vermicast samples were analyzed with SEM and the image showed significant variation. The FT-IR spectrum analysis showed reduction of aliphatic/aromatic $(\mathrm{C}=\mathrm{C}$ and $\mathrm{OH}) \mathrm{com}$ pounds in the vermicompost. Thus, the present study significantly highlights the vermifiltration technology in treating distillery effluent.

Keywords: Earthworms, Distillery Effluents, Vermifiltration, HRT, Vermicast, FT-IR.

\section{Article Info}

https://doi.org/

10.31018/jans.v11i4.2112

Received: June 18, 2019

Revised: October 26, 2019

Accepted: November 16, 2019

\section{How to Cite}

Kannadasan, N. et al (2019). Potential of distillery effluents for safe water through vermifiltration. Journal of Applied and Natural Science, 11(4): 768 - 777 https://doi.org/ 10.31018/jans.v11i4.2112

\section{INTRODUCTION}

Pollution is a gift of rapid industrial revolution and excessive exploitation of natural resources. Use of water in India is spectacular as more water consuming industries like Distillery, Textiles, Dye, Diary, Sugar, Tannery, Paper, Soap and Brewery are housed along various cities and accumulate sludge on land wastewater into rivers. The above mentioned industrial waste (sludge) and wastewater should be converted into useful manner. To avoid pollution problem the sludge and wastewater must be recycled. Both in developed and developing countries in modern age the solid waste is increasing in bulk (Abdel-Shafy and Mansour, 2018).

The government of numerous countries have striven to find solutions to reduce this problem.
Distillery listed at the top of Red Category industry among the pollution industries as per Ministry of Environment and Forests (MoEF). The industry generates biomethananted spentwash of $8-9^{\circ}$ brix is concentrated from approximately $320 \mathrm{M}^{2} /$ day to $51 \mathrm{M}^{3} /$ day (CPCB, 2018). According to Chowdhary et al. (2017), the distillery units in India increased up to 319 with their annual production of alcohol and waste water making a serious pollution threat. It is mandatory for distilleries to take appropriate measures to check the disposal of wastewater.

Vermifiltration (VF) has been studied extensively due to its effectiveness in removing pollutant form wastewater, and its positive effects on the environment (Aguilera, 2003). Organic wastewater treatment using vermifiltration is the safe and the best one. This technique is first advocated by the 
late professor Jose Toha of Chile University in 1992 (Wang et al., 2010). Sinha and his group investigated the potential of the VF system in treatment of dairy industry effluent (Sinha et al., 2008). They reported that earthworms by biodegradation remove BOD over $98 \%$, COD $80-90 \%$, TDS by $90-92 \%$. Ghatnekar et al. (2010) reported VF as an efficient system to remove COD and BOD load of wastewater generated from gelatin industry. The proposed research work aimed at appraising the conversion of distillery industrial effluents and sludge retreating wastewater into through vermifiltration us in the earthworm Eudrilus eugeniae, and their effect on physico-chemical parameter for the benefit of the environment.

\section{MATERIALS AND METHODS}

Collection and culturing of worms: The earthworms Eudrilus eugeniae, used for the present study was purchased from the Periyar Research Organization for Bio-Technique and Ecosystem (PROBE), Periyar Maniyammai University, Vallam, Tanjore Dist, Tamil Nadu and cultured in cement tanks for further studies. The earthworms were reared in garden soil. The vermibed of dimension 4 (length) $\times 2$ (breadth) $\times 4 / 4$ feet (height) sufficient for $1 \mathrm{Kg}(1,000$ to 1,500$)$ worms with moisture 35 - 45\% was made. Entry of predators into the vermibed is presented by using nylon net. Optimum moisture was maintained by pouring waster daily.

Collection of samples: Distillery Effluent (DE) samples were collected from Trichy Distilleries, Senthanirpuram, Tiruchirappalli District. Only these samples were used for the experiment after proper dilution. Physico-chemical parameter were analyzed in the distillery effluent at Environmental Biotechnology Laboratory, P.G. and Research Department of Zoology, Periyar E.V.R College, Tiruchirappalli.

Non-vermifilter (NVF) and vermifilter (VF): The size of the VF reactor was $36 \mathrm{~cm}$ (long) $\times 36 \mathrm{~cm}$ (wide) $\times 36 \mathrm{~cm}$ (height). It had an upper filtering unit and lower collection unit. Filtering units were filled with gravel, sand and garden soil. The bottom most layers were filled up to $7 \mathrm{~cm}$ with gravel aggregated of size $10-20 \mathrm{~mm}$, followed by gravel by size 2 - $4 \mathrm{~mm}$ size up to $7 \mathrm{~cm}$, sand of size 1 $2 \mathrm{~mm}$ up to $7 \mathrm{~cm}$ and the top most layer with garden soil up to $7 \mathrm{~cm}$. VF reactor is same as that of the NVF reactor except for the presence of earthworms.

Experimental design and management: Plastic drum of $10 \mathrm{~L}$ capacity were filled with $6 \mathrm{~L}$ of effluents (DE). These drums were kept on an elevated platform just near the VF unit. One end of the flexible rubber tube was fitted to the tap of the plastic drum and the other end was placed over the VF unit. The effluent distribution system consisted of simple 0.5 inch flexible rubber pipe with hole for trickling effluent above the soil surface of vermibed. Effluents percolated down through various layers in the vermifilter bed and at the end were collected in a bottom chamber. When the experiment started, $1 \mathrm{~kg}$ (1,000 to 1,500 worms) earthworms were introduced in the soil bed. The hydraulic retention time in the vermifilter bed was kept uniformly for 8 - 10 hours in all experiments.

Hydraulic retention time: HRT, the time the wastewater remain in contact with the worm is on essential factor for wastewater treatment. HRT is essential and it depends on the flow rate of wastewater to the VF unit, the volume of soil profile and quality of soil used. High hydraulic loading rate varies among the nature of the soil according to Sinha et.al., (2008), which greatly reduce the treatment efficiency.

Analysis of physico-chemical parameters: VF and NVF filtered water were collected at the collection unit and analyzed for physico-chemical parameters like $\mathrm{pH}$, Electrical Conductivity, Biological Oxygen Demand, Chemical Oxygen Demand, Total Solids, Total Suspended Solids and Total Dissolved Solids. The physico-chemical parameters were analyzed using standard methods (APHA, 2012). All the samples were analyzed in triplicate and the results were averaged during a working condition.

Analysis of soil layer and vermicasts: Using horizon-wise collection method, soil sample were collected both in control and vermicast. Samples of topsoil upto $7 \mathrm{~cm}$ were collected from sampling points at intervals of 7 days. Subsequently, earthworms were removed from the substrates. Total nitrogen was measured by micro Kjeldahl method (Jackson, 1975). Extractable phosphorous was determined (Olsen et.al., 1954). Exchangeable elements ( $\mathrm{K}, \mathrm{Ca}$ and $\mathrm{Mg}$ ) were determined using ammonium acetate extractable method (Simard, 1993) and the vermicasts samples were measured/estimated in the Non-vermifilter (NVF) and vermicast samples.

Morphology of the vermicast: Vermicasts were collected from vermibed of control and DE experimental samples (VF-75\%, VF-50\%, VF-25\%) from different sampling points. Samples from the same depth were mixed to give one composite sample. Finally, from the samples casts were freeze-dried, sieved $(<2 \mathrm{~mm})$ and their surface structure was analyzed using a Scanning Electron Microscope (SEM).

FT-IR Spectra analysis: The Fourier transform infrared (FT-IR) spectra used to find out the major functional groups in the earthworm cast (He et al., 2011 and Xing et al., 2011).

Statistical analysis: The data entry and Analysis of Variance (ANOVA) were analyzed using SPSS version-16.0. One-way ANOVA was used to test differences in the related physico-parameters of effluents using of VF systems under similar influ- 
ent conditions. Duncan's multiple range tests was used to further assess differences among VF systems that were significant in ANOVA. The statistical significance were at $p<0.05$ probability levels.

\section{RESULTS AND DISCUSSION}

Physico-chemical characteristics: The quality of DE in terms of physico-chemical characteristics are given in Tables $1-2$. The $\mathrm{pH}$ value of raw DE was acidic in nature 4.5 , the raw spent wash is acidic in nature and the $\mathrm{pH}$ values of distillery effluents range from 3.5 to 5.0 . But when it was diluted with different dilution $25 \%, 50 \%$ and $75 \%$.
The $\mathrm{pH}$ values of raw, diluted and filtered effluent from VF and NVF units were observed. The average $\mathrm{pH}$ of $\mathrm{DE}$ was $5.56 \pm 0.02^{\mathrm{a}}$ in $75 \%, 5.54 \pm$ $0.01^{\mathrm{a}}$ in $50 \%$ and $5.54 \pm 0.02^{\mathrm{a}}$ in $25 \%$. The $\mathrm{pH}$ recorded after the treatment was $6.12 \pm 0.02^{\mathrm{a}}$ in $75 \%$, $7.07 \pm 0.01^{\mathrm{b}}$ in $50 \%, 7.36 \pm 0.01^{\mathrm{c}}$ in $25 \% \mathrm{NVF}$ and $7.02 \pm 0.02^{\mathrm{a}}$ in $75 \%, 7.51 \pm 0.01^{\mathrm{b}}$ in $50 \%, 7.61 \pm$ $0.01^{\mathrm{c}}$ in $25 \%$ VF unit. From ANOVA test, it showed significant difference in values of $\mathrm{pH}$, when worm density is varied, but no significant difference when concentration is varied throughout the VF process $(p<0.05)$.

The result of the present study is in accordance

Table 1. Physico-chemical characteristics of the raw and diluted distillery effluent.

\begin{tabular}{llccc}
\hline \multirow{2}{*}{ Parameters } & \multirow{2}{*}{ Raw Effluent } & \multicolumn{3}{c}{ Diluted Distillery Effluent } \\
\cline { 3 - 5 } & & $\mathbf{7 5 \%}$ & $\mathbf{5 0 \%}$ & $\mathbf{2 5 \%}$ \\
\hline $\mathrm{pH}$ & 4.5 & $5.56 \pm 0.02^{\mathrm{a}}$ & $5.54 \pm 0.01^{\mathrm{a}}$ & $5.54 \pm 0.02^{\mathrm{a}}$ \\
$\mathrm{EC}(\mathrm{mS} / \mathrm{cm})$ & 18.86 & $15.47 \pm 0.35^{\mathrm{c}}$ & $12.34 \pm 0.03^{\mathrm{b}}$ & $7.52 \pm 0.02^{\mathrm{a}}$ \\
$\mathrm{BOD}(\mathrm{mg} / \mathrm{L})$ & 32533.00 & $18100.00 \pm 3.60^{\mathrm{c}}$ & $11700.00 \pm 21.36^{\mathrm{b}}$ & $5863.67 \pm 3.21^{\mathrm{a}}$ \\
$\mathrm{COD}(\mathrm{mg} / \mathrm{L})$ & 97600.00 & $54400.00 \pm 50.00^{\mathrm{c}}$ & $35200.00 \pm 50.00^{\mathrm{b}}$ & $17600.00 \pm 17.55^{\mathrm{a}}$ \\
$\mathrm{TS}(\mathrm{mg} / \mathrm{L})$ & 70000.00 & $57200.00 \pm 200.00^{\mathrm{c}}$ & $35100.00 \pm 100.00^{\mathrm{b}}$ & $23200.00 \pm 251.66^{\mathrm{a}}$ \\
$\mathrm{TSS}(\mathrm{mg} / \mathrm{L})$ & 8000.00 & $7116.67 \pm 104.08^{\mathrm{c}}$ & $5073.33 \pm 87.36^{\mathrm{b}}$ & $4143.33 \pm 128.97^{\mathrm{a}}$ \\
TDS $(\mathrm{mg} / \mathrm{L})$ & 62000.00 & $50100.00 \pm 104.08^{\mathrm{c}}$ & $32000.00 \pm 25.16^{\mathrm{b}}$ & $19100.00 \pm 138.92^{\mathrm{a}}$ \\
\hline
\end{tabular}

${ }^{*}$ Results are the mean value in triplicates \pm SD with significant difference at $p<0.05$.

Table 2. Physico-chemical characteristics of the distillery effluent at different concentration.

\begin{tabular}{|c|c|c|c|c|c|c|}
\hline \multirow{2}{*}{ Parameters } & \multicolumn{3}{|c|}{ Non-Vermifilter (NVF) } & \multicolumn{3}{|c|}{ Vermifilter (VF) } \\
\hline & $75 \%$ & $50 \%$ & $25 \%$ & $75 \%$ & $50 \%$ & $25 \%$ \\
\hline $\mathrm{pH}$ & $6.12 \pm 0.02^{\mathrm{a}}$ & $7.07 \pm 0.01^{b}$ & $7.36 \pm 0.01^{\mathrm{C}}$ & $7.02 \pm 0.02^{\mathrm{a}}$ & $7.51 \pm 0.01^{b}$ & $7.61 \pm 0.01^{\mathrm{c}}$ \\
\hline $\mathrm{EC}(\mathrm{mS} / \mathrm{cm})$ & $6.53 \pm 0.01^{\mathrm{c}}$ & $5.41 \pm 0.01^{\mathrm{b}}$ & $4.73 \pm 0.03^{\mathrm{a}}$ & $3.95 \pm 0.03^{c}$ & $2.03 \pm 0.04^{b}$ & $1.74 \pm 0.01^{\mathrm{a}}$ \\
\hline $\mathrm{BOD}_{5}(\mathrm{mg} / \mathrm{L})$ & $3092.67 \pm 2.51^{\mathrm{c}}$ & $2027.00 \pm 2.64^{b}$ & $1066.00 \pm 4.00^{\mathrm{a}}$ & $929.33 \pm 27.68^{c}$ & $527.67 \pm 25.42^{b}$ & $425.00 \pm 3.60^{\mathrm{a}}$ \\
\hline $\operatorname{COD}(\mathrm{mg} / \mathrm{L})$ & $9265.00 \pm 15.00^{c}$ & $6058.33 \pm 20.20^{\mathrm{b}}$ & $2809.33 \pm 9.01^{a}$ & $3174.00 \pm 22.71^{\mathrm{c}}$ & $1615.00 \pm 20.22^{b}$ & $1250.67 \pm 25.71^{\mathrm{a}}$ \\
\hline $\mathrm{TS}(\mathrm{mg} / \mathrm{L})$ & $23100.00 \pm 152.75^{c}$ & $14100.00 \pm 76.37^{b}$ & $11000.00 \pm 36.05^{a}$ & $7016.67 \pm 20.81^{c}$ & $6036.67 \pm 55.07^{b}$ & $3016.67 \pm 15.27^{\mathrm{a}}$ \\
\hline $\mathrm{TSS}(\mathrm{mg} / \mathrm{L})$ & $6080.00 \pm 75.49^{c}$ & $4026.67 \pm 25.16^{b}$ & $3011.67 \pm 10.40^{a}$ & $3011.00 \pm 16.52^{c}$ & $2254.33 \pm 437.92^{b}$ & $1011.67 \pm 10.40^{\mathrm{a}}$ \\
\hline TDS (mg/L) & $17100.00 \pm 83.86^{c}$ & $12100.00 \pm 51.31^{\mathrm{b}}$ & $8028.33 \pm 25.65^{a}$ & $5005.67 \pm 5.13^{c}$ & $4115.67 \pm 194.31^{b}$ & $2005.00 \pm 5.00^{\mathrm{a}}$ \\
\hline
\end{tabular}

Results are the mean value in triplicates \pm SD with significant difference at $p<0.05$.

Table 3. Level of macro and micronutrients in DE vermicast at different concentrations.

\begin{tabular}{llcccc}
\hline S. N. & Parameters & Control & VF $-\mathbf{7 5 \%}$ & VF $-\mathbf{5 0 \%}$ & VF $-\mathbf{2 5 \%}$ \\
\hline 1 & Total Nitrogen (\%) & $1.03 \pm 0.01^{\mathrm{c}}$ & $1.78 \pm 0.01^{\mathrm{b}}$ & $1.82 \pm 0.01^{\mathrm{a}}$ & $1.82 \pm 0.01^{\mathrm{a}}$ \\
2 & Total Phosphorus (\%) & $0.16 \pm 0.01^{\mathrm{b}}$ & $0.23 \pm 0.01^{\mathrm{a}}$ & $0.23 \pm 0.01^{\mathrm{a}}$ & $0.24 \pm 0.00^{\mathrm{a}}$ \\
3 & Total Potassium (\%) & $1.03 \pm 0.01^{\mathrm{c}}$ & $2.14 \pm 0.04^{\mathrm{b}}$ & $2.11 \pm 0.00^{\mathrm{c}}$ & $2.15 \pm 0.00^{\mathrm{a}}$ \\
4 & Total Calcium (\%) $_{5}$ & $1.64 \pm 0.01^{\mathrm{d}}$ & $2.02 \pm 0.01^{\mathrm{c}}$ & $2.05 \pm 0.01^{\mathrm{b}}$ & $2.07 \pm 0.01^{\mathrm{a}}$ \\
5 & Total Magnesium (\%) & $1.05 \pm 0.01^{\mathrm{d}}$ & $2.25 \pm 0.01^{\mathrm{c}}$ & $2.46 \pm 0.01^{\mathrm{b}}$ & $2.86 \pm 0.01^{\mathrm{a}}$ \\
\hline
\end{tabular}

Results are the mean value in triplicates \pm SD with significant difference at $p<0.05$.

Table 4. Assignment of typical infrared bands in FT-IR spectra of OM (NVF and VF).

\begin{tabular}{|c|c|c|c|}
\hline $\begin{array}{l}\text { Wave Number } \\
(\mathrm{cm}-1)\end{array}$ & Vibration & $\begin{array}{lll}\begin{array}{l}\text { Functional Group or } \\
\text { Component }\end{array} & \\
\end{array}$ & References \\
\hline $3700-3400$ & $\mathrm{OH}$ stretch & $\begin{array}{l}\text { Hydroxyl (Polysaccharide) } \\
\text { \& Amino Group }\end{array}$ & Simkovic et al., 2008 \\
\hline $1649-1521$ & $\mathrm{C}=\mathrm{C}$ stretch & Aromatic Group & Karthika et al., 2015 \\
\hline $1490-1340$ & $\begin{array}{l}\mathrm{OH} \text { deformation, Symmet- } \\
\text { ric COO- \& OH stretch }\end{array}$ & $\begin{array}{l}\text { Aliphatic, Phenols \& Car- } \\
\text { boxylic Groups }\end{array}$ & Hafidi et al., 2005 \\
\hline $1095-1030$ & $\begin{array}{l}\text { Combination of } \mathrm{C}-\mathrm{O}-\mathrm{C} \\
\text { Stretching \& } \mathrm{O}-\mathrm{H} \text { defor- } \\
\text { mation }\end{array}$ & Polysaccharides & $\begin{array}{l}\text { Grube et al., 2006; Contreras- } \\
\text { Ramos et al., 2004; Ravindran } \\
\text { et al., } 2008\end{array}$ \\
\hline $1030-790$ & Si-O-Si stretch & Clay minerals & $\begin{array}{l}\text { Senthil kumar et al., } 2013 \\
\text { Carrasquero-Duran and Flores, }\end{array}$ \\
\hline $850-750$ & C - O stretch & Carbonate & $\begin{array}{l}\text { 2009; Contreras-Ramos et al., } \\
\text { 2004; Ravindran et al., } 2008\end{array}$ \\
\hline $475-460$ & Si-O stretch & Silica & Nayak and Singh, 2007 \\
\hline
\end{tabular}




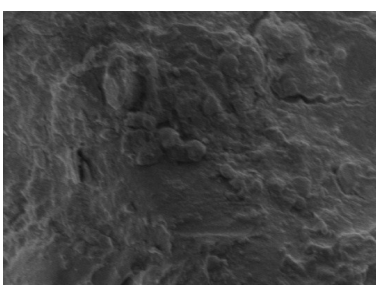

DE Non-Vermifilter sludge

Fig. 1. SEM images of after NVF Sludge and VF vermicast

with Azuar and Ibrahim (2012) and Garkal and Jadhao (2014) applied the VF technology in treating the palm oil mill effluent. Earthworm has an inbuilt $\mathrm{pH}$ buffering ability by increasing the $\mathrm{pH}$, hence neutralizing the sewage wastewater $\mathrm{pH}$ (Manyuchi et al., 2012). The $\mathrm{pH}$ value difference between control and VF could be related to earthworm mediated rapid mineralization of organic fractions of wastewater (Rajpal et. al., 2012). The $\mathrm{pH}$ of effluent from all the VFs increased initially during the treatment and then settled to neutral range signifying the inherent capability of earthworms to act as buffering agent to neutralize (Arora et al., 2014).

The Electrical Conductivity (EC) of DE showed significant changes after treatment through a filtration system in both NVF and VF processes. The EC of the raw and diluted $(75 \%, 50 \%$ and $25 \%$ )
DE was $18.86(\mathrm{mS} / \mathrm{cm})$ and $15.47 \pm 0.35^{\mathrm{c}}$ in $75 \%$, $12.34 \pm 0.03^{\mathrm{b}}$ in $50 \%, 7.52 \pm 0.02^{\mathrm{a}}(\mathrm{mS} / \mathrm{cm})$ in $25 \%$. The EC of treated DE was $6.53 \pm 0.01^{\mathrm{c}}, 5.41$ $\pm 0.01^{\mathrm{b}}, 4.73 \pm 0.03^{\mathrm{a}}(\mathrm{mS} / \mathrm{cm})$ in NVF and $3.95 \pm$ $0.03^{\mathrm{c}}$ in $75 \%, 2.03 \pm 0.04^{\mathrm{b}}$ in $50 \%, 1.74 \pm 0.01^{\mathrm{a}}$ $(\mathrm{mS} / \mathrm{cm})$ in $25 \%$ VFs. The difference between NVF and VF reactor was statistically significant. The microbial activity of earthworms gut increase the EC of the wastewater by mieralization than control. Increased EC of substrate may be the result of release of minerals from the gut of earthworm (Kaur et al., 2010 and Suthar, 2010).

Biochemical Oxygen Demand $\left(\mathrm{BOD}_{5}\right)$ is the most important parameters used to determine the degree of pollution of aquatic habit. Table 1 - 2 indicates the BOD of the raw DE as $32533.00 \mathrm{mg} / \mathrm{L}$. The BOD of raw and diluted DE was $18100.00 \pm$ $3.60^{\mathrm{c}}$ in $75 \%, 11700.00 \pm 21.36^{\mathrm{b}}$ in $50 \%$ and $5863.67 \pm 3.21^{\mathrm{a}} \mathrm{mg} / \mathrm{L}$ in $25 \%$. The level of BOD removal from the DE in VF, was $929.33 \pm 27.68^{\mathrm{C}}$ in $75 \%, 527.67 \pm 25.42^{\mathrm{b}}$ in $50 \%$ and $425.00 \pm 3.60^{\mathrm{a}}$ $\mathrm{mg} / \mathrm{L}$ in $25 \%$. Where as for NVF it was $3092.67 \pm$ $2.51^{\mathrm{c}}$ in $75 \%, 2027.00 \pm 2.64^{\mathrm{b}}$ in $50 \%$ and 1066.00 $\pm 4.00^{\mathrm{a}} \mathrm{mg} / \mathrm{L}$ in $25 \%$. The average BOD removal from the DE by earthworm is over $95 \%$, while that without earthworms is over $80 \%$ for NVF. This could be due to the symbiotic activity of earthworms and aerobic microbes. The decomposition of organic waste by the symbiotic activity of earth-

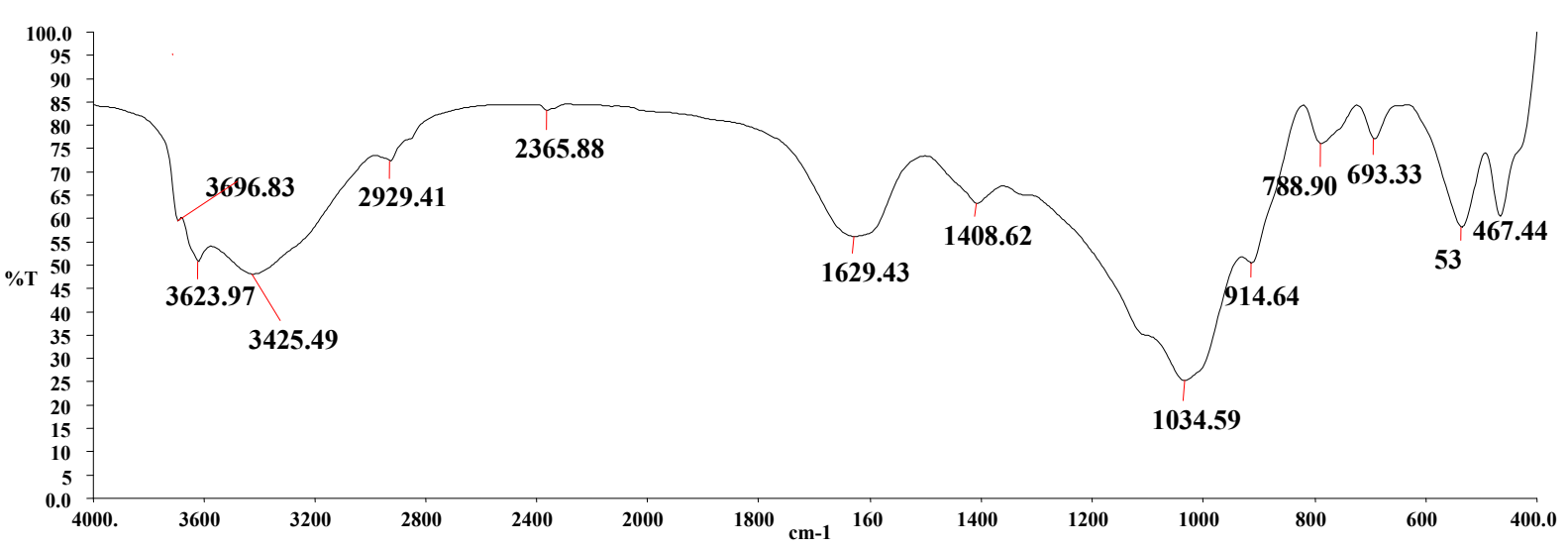

Fig. 2. FT-IR spectra of the DE sample of vermicast produced by vermibed in NVF - $75 \%$

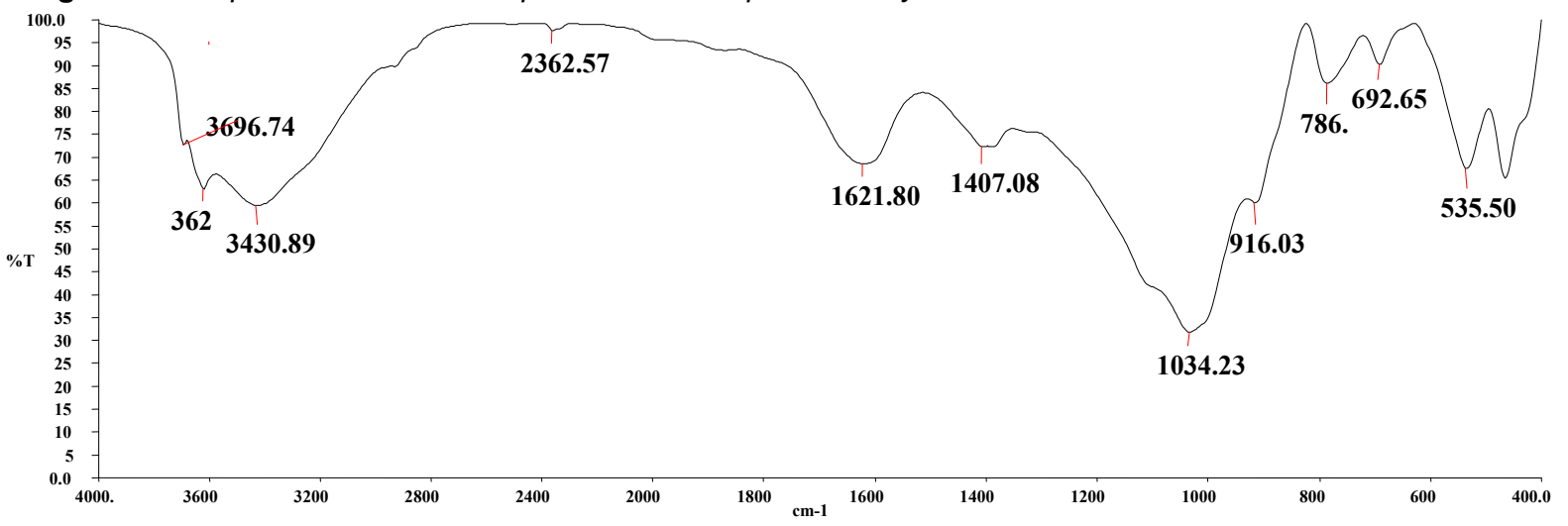

Fig. 3. FT-IR spectra of the DE sample of vermicast produced by vermibed in NVF- $50 \%$. 


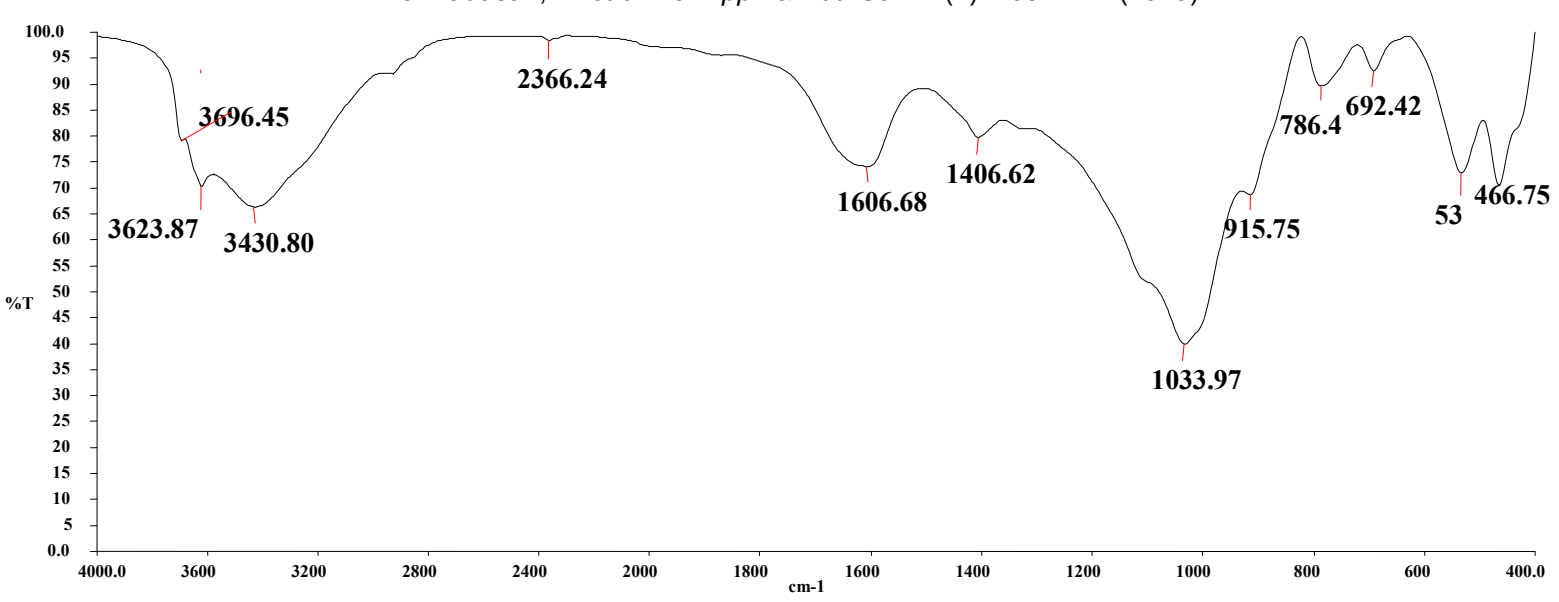

Fig. 4. FT-IR spectra of the DE sample of vermicast produced by vermibed in NVF $-25 \%$.

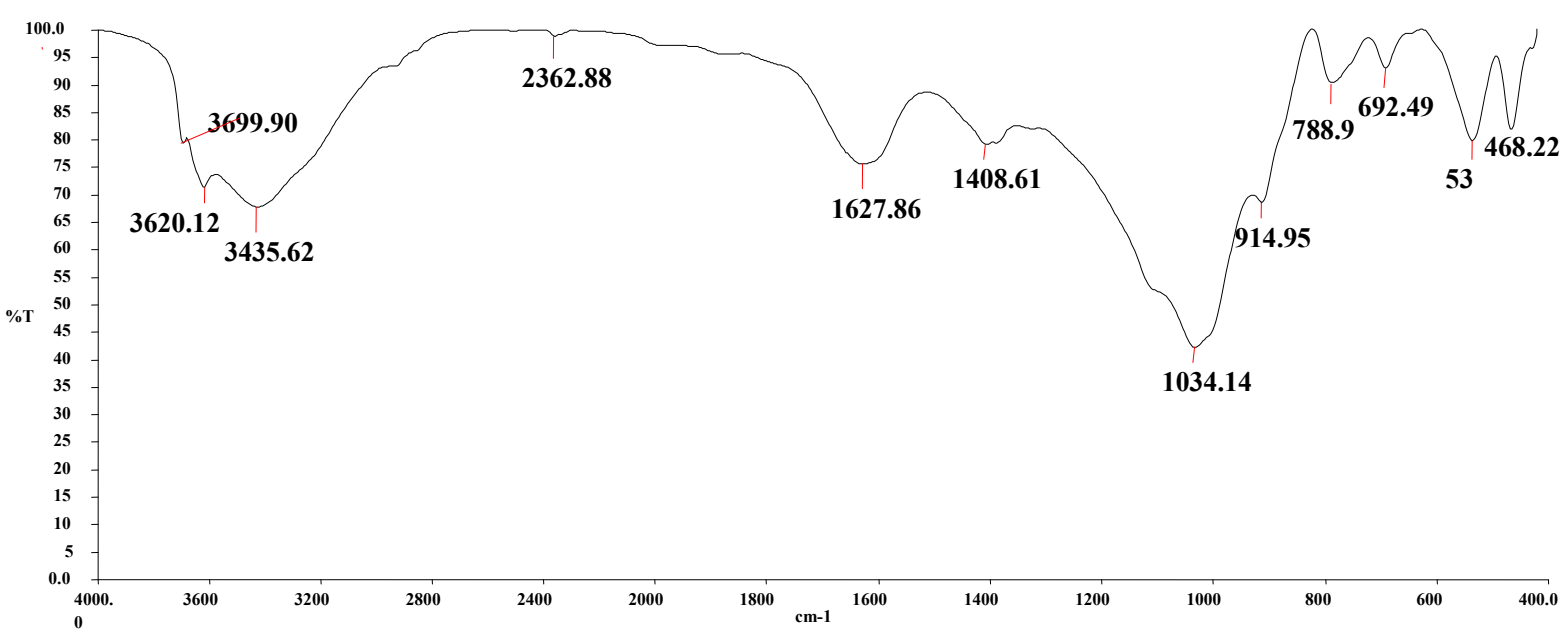

Fig. 5. FT-IR spectra of the DE sample of vermicast produced by vermibed in VF - 75\%.

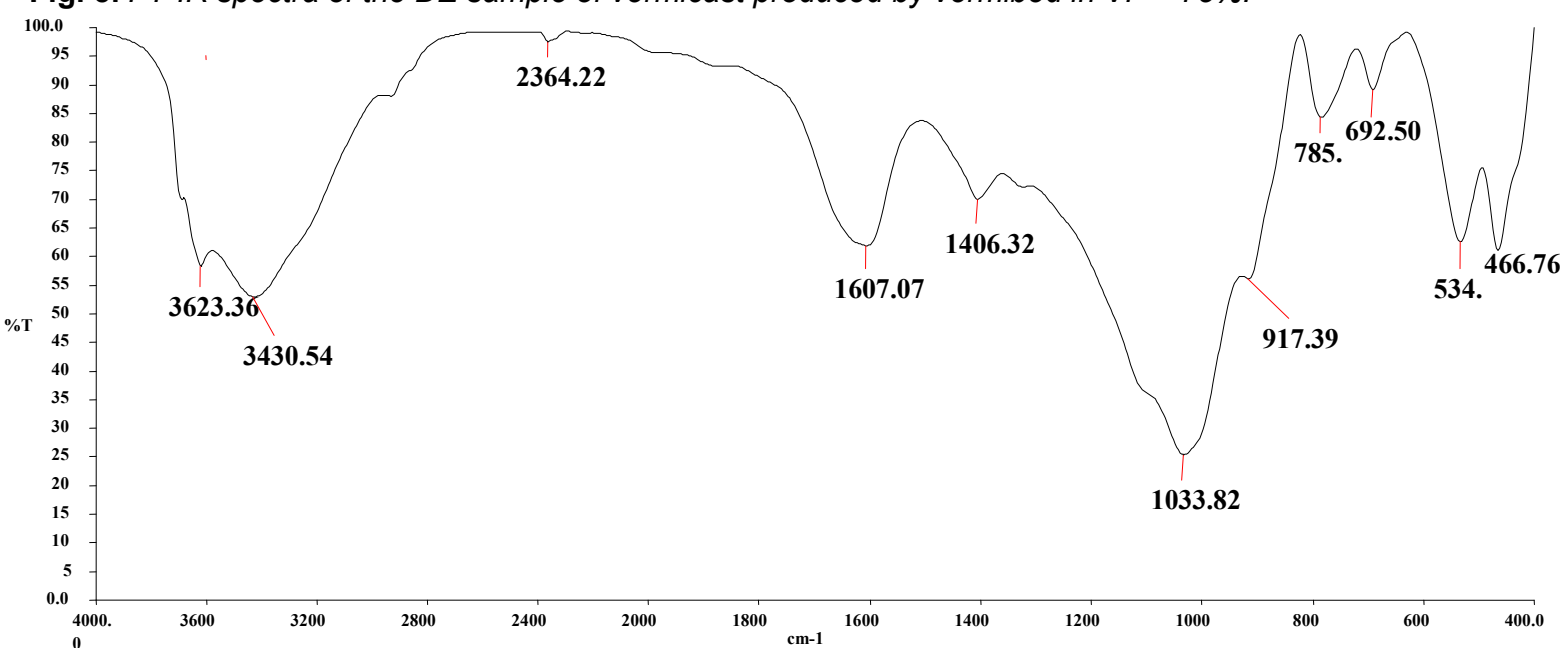

Fig. 6. FT-IR spectra of the DE sample of vermicast produced by vermibed in VF - 50\%.

worm and aerobic microbes acts as biological catalysts to reduce the BOD of wastewater (Tomar and Suthar, 2011; Sinha et al., 2008; Ghatnekar et al., 2010 and Azuar and Ibrahim, 2012).

The values of Chemical Oxygen Demand (COD) in filterate from VF and NVF is illustrated in Table
1 and 2. The data showed that the COD of effluent was significantly low $(p<0.05)$ in VF and NVF units as compared to influent as mentioned in the Table. COD is an important indicator of chemical load of industrial and domestic wastewater. The COD of the raw DE was $97600.00 \mathrm{mg} / \mathrm{L}$, diluted DE were $54400.00 \pm 50.00^{\mathrm{C}}$ in $75 \%, 35200.00 \pm$ 


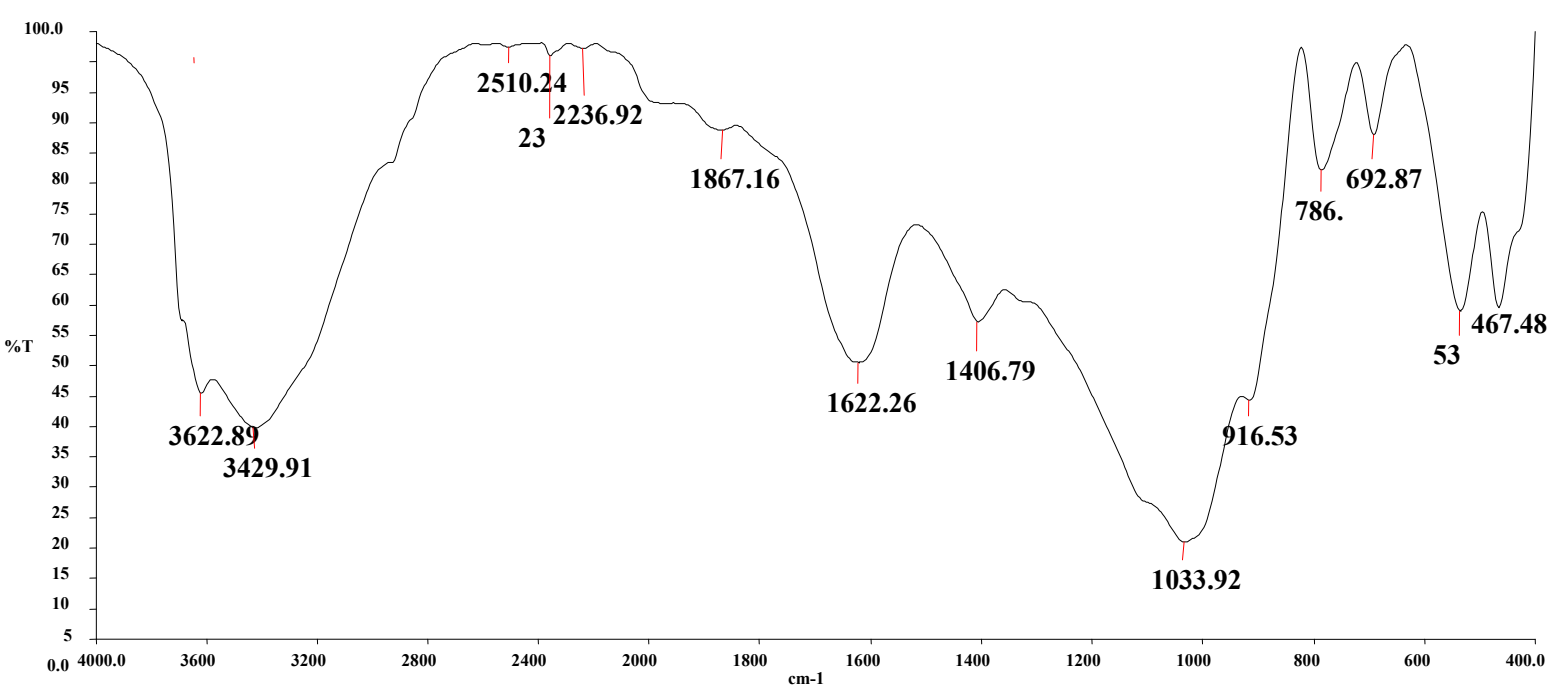

Fig. 7. FT-IR spectra of the DE sample of vermicast produced by vermibed in VF $-25 \%$.

$50.00^{\mathrm{b}}$ in $50 \%$ and $17600.00 \pm 17.55^{\mathrm{a}} \mathrm{mg} / \mathrm{L}$ in $25 \%$. COD removal of the treated DE in different dilution in VF was $3174.00 \pm 22.71^{\mathrm{c}}$ in $75 \%$, $1615.00 \pm 20.22^{\mathrm{b}}$ in $50 \%$ and $1250.67 \pm 25.71^{\mathrm{a}}$ $\mathrm{mg} / \mathrm{L}$ in $25 \%$, while for NVF it was $9265.00 \pm$ $15.00^{\mathrm{C}}$ in $75 \%, 6058.33 \pm 20.20^{\mathrm{b}}$ in $50 \%$ and $2809.33 \pm 9.01^{\mathrm{a}} \mathrm{mg} / \mathrm{L}$ in $25 \%$. In case of VF reactor, the average removal efficiency of COD was recorded as $90 \%$, while in NVF the COD reduction was represented as $80 \%$. The acceleration of microbial colonization in variables by assimilable carbon and other nutrients reduce $46 \%$ of volatile suspended solids and thereby reduce the COD by vermifilteration (Wang et al., 2010; Zhao et al., 2010; Aira et al., 2007 and Zhao et al., 2010).

Total Solids (TS) significantly reduced by VF ( $p<$ 0.05 ) as shown in Table 1 and 2, the raw DE had $70000.00 \mathrm{mg} / \mathrm{L}$. These values decrease after dilutions of DE. It was $57200.00 \pm 200.00^{c}$ in $75 \%$, $35100.00 \pm 100.00^{\mathrm{b}}$ in $50 \%$ and $23200.00 \pm$ $251.66^{\mathrm{a}} \mathrm{mg} / \mathrm{L}$ in $25 \%$. DE filtered from VF was $7016.67 \pm 20.81^{c}$ in $75 \%, 6036.67 \pm 55.07^{b}$ in $50 \%$ and $3016.67 \pm 15.27^{\mathrm{a}} \mathrm{mg} / \mathrm{L}$ in $25 \%$, while in NVF it was $23100.00 \pm 152.75^{\mathrm{c}}$ in $75 \%, 14100.00$ $\pm 76.37^{\mathrm{b}}$ in $50 \%$ and $11000.00 \pm 36.05^{\mathrm{a}} \mathrm{mg} / \mathrm{L}$ in $25 \%$. The overall TS removal efficiency in both experimental plants were $80 \%$ in VF and $60 \%$ in NVF. Total Suspended Solids (TSS) and Total Dissolved Solids (TDS) showed a drastic reduction during NVF and VF (Table 1 and 2). The concentration of both TSS and TDS were reduced during VF significantly $(p<0.05)$.

The TSS and TDS were $8000.00 \mathrm{mg} / \mathrm{L}$ and $62000.00 \mathrm{mg} / \mathrm{L}$ in raw DE. The TSS and TDS of the diluted DE was $7116.67 \pm 104.08^{\mathrm{C}}$ in $75 \%$, $5073.33 \pm 87.36^{\mathrm{b}}$ in $50 \%$ and $4143.33 \pm 128.97^{\mathrm{a}}$ $\mathrm{mg} / \mathrm{L}$ in $25 \%$ and $50100.00 \pm 104.08^{\mathrm{c}}$ in $75 \%$, $32000.00 \pm 25.16^{\mathrm{b}}$ in $50 \%$ and $19100.00 \pm$ $138.92^{\mathrm{a}} \mathrm{mg} / \mathrm{L}$ in $25 \%$. The results of the resent study suggest the efficiency of vermifiltration pro- cess in removing the total solid fraction of effluent. The TSS and TDS removal rate were high in VF unit $\left(3011.00 \pm 16.52^{\mathrm{c}}\right.$ in $75 \%, 2254.33 \pm 437.92^{\mathrm{b}}$ in $50 \%$ and $1011.67 \pm 10.40^{\mathrm{a}} \mathrm{mg} / \mathrm{L}$ in $25 \%$ and $5005.67 \pm 5.13^{\mathrm{c}}$ in $75 \%, 4115.67 \pm 194.31^{\mathrm{b}}$ in $50 \%$ and $2005.00 \pm 5.00^{\mathrm{a}} \mathrm{mg} / \mathrm{L}$ in $25 \%$ ) than NVF system $\left(6080.00 \pm 75.49^{\mathrm{c}}\right.$ in $75 \%, 4026.67 \pm 25.16^{\mathrm{b}}$ in $50 \%$ and $3011.67 \pm 10.40^{\circ} \mathrm{mg} / \mathrm{L}$ in $25 \%$ and $17100.00 \pm 83.86^{\mathrm{c}}$ in $75 \%, 12100.00 \pm 51.31^{\mathrm{b}}$ $50 \%, 8028.33 \pm 25.65^{\mathrm{a}} \mathrm{mg} / \mathrm{L}$ in $25 \%$ ). The VF unit significantly removed the TSS and TDS from the DE about $80 \%$ and $88 \%$, while the NVF bed indicated $70 \%$ and $65 \%$ decrease. The reduction in total solid waste may be attributed to the earthworms biodegradation using gut microbes (Kumar et al., 2014).

During VF process, a tortuous behavior for TSS concentration was also observed accordingly with Sharma et al., (2014), Sharma and Kazmi, (2014). From literature available it has been evidenced that these organic and inorganic particles are further trapped in the voids of vermifilter and causes high removal efficiency of TSS and TDS from wastewater (Sinha et al., 2008). According to Cooper et al. (1996) and Vymazal et al. (1998) the suspended solids that are not removed through pre-treatment system are effectively removed by filtration and settlement processes. The efficacy of VFs in TDS and TSS removal is also reported by earlier authors were comparable with the present results.

Effect of the physico-chemical characteristics of vermicast: The percentage of Total Nitrogen (TN) showed an increase in DE sludge treated with Eudrilus eugeniae $1.78 \pm 0.01^{\mathrm{b}}$ in $75 \%, 1.82 \pm$ $0.01^{\mathrm{a}}$ in $50 \%, 1.82 \pm 0.01^{\mathrm{a}}$ in $25 \%$ and $1.03 \pm$ $0.01^{\mathrm{c}}$ in control (Table-3). Significant variation $(p<0.05)$ was observed in $\mathrm{TN}$, as compared to control. The present data clearly suggested that nitrogen increase in vermicomposted material was 
directly related to the physico-chemical properties of the initial substrates as compared with the results of Battacharya et al. (2004). Bedding materials modify the physical structure of waste and also accelerate the waste mineralization rate in vermibeds. Other reports on vermicomposting (Suthar, 2008) have reported a higher $\mathrm{N}$ increase at the end. Decaying tissues of dead worms are also one of the factors for TN increase in significant amount.

The elevated level of Total Phosphorus (TP) content was recorded in DE sludge treated with earthworm $0.23 \pm 0.01^{\mathrm{a}}$ in $75 \%, 0.23 \pm 0.01^{\mathrm{a}}$ in $50 \%$, $0.24 \pm 0.00^{\mathrm{a}}$ in $25 \%$ and $0.16 \pm 0.01^{\mathrm{b}}$ in control (Table 3). Recently Suthar (2009) reported higher content of available $P$ in organic wastes due to concentration of sludge in bedding material as observed in the present result. Difference in TP content in all the reactors in all the sampling days were significant $(p<0.05)$ in the present study. The range of Total Potassium (TK) content was recorded in DE sludge treated with Eudrilus eugeniae $2.14 \pm 0.04^{\mathrm{b}}$ in $75 \%, 2.11 \pm 0.00^{\mathrm{c}}$ in $50 \%$, $2.15 \pm 0.00^{\mathrm{a}}$ in $25 \%$ and $1.03 \pm 0.01^{\mathrm{c}}$ in control (Table-3). The results of this study agree with previous report of Suthar, (2009) that the vermicomposting process accelerates the microbial populations in waste and subsequently enriches the end product with most available forms of plant nutrients. Earthworms are very sensitive to ammonia and cannot survive in organic waste containing high level of cation (Dominguez, 2004).

The observed values of Total Calcium (TCa) and Total Magnesium (TMg) present in the control were found to be $1.64 \pm 0.01^{\mathrm{d}}$ and $1.05 \pm 0.01^{\mathrm{d}}$. Analysis of total $\mathrm{Ca}$ and $\mathrm{Mg}$ present in the $\mathrm{DE}$ sludge treated with earthworms Eudrilus eugeniae was found to be $2.02 \pm 0.01^{\mathrm{c}}$ in $75 \%, 2.05 \pm 0.01^{\mathrm{b}}$ in $50 \%, 2.07 \pm 0.01^{\mathrm{a}} 25 \%$ and $2.25 \pm 0.01^{\mathrm{c}}$ in $75 \%, 2.46 \pm 0.01^{\mathrm{b}}$ in $50 \%$, and $2.86 \pm 0.01^{\mathrm{a}}$ in $25 \%$ (Table-3). Ca and $\mathrm{Mg}$ increased significantly $(p<0.05)$ from control to different concentration of VF treatments. The increase in Ca had a higher proportion of bedding materials. Earthworm drives the mineralization process efficiently which results in higher concentration of $\mathrm{Mg}$ in the vermicompost (Suthar, 2008; 2009 and Kannadasan et al., 2013).

Morphology of vermicast: Scanning Electron Microscope (SEM) was presented with the changes of physico-chemical structure of the cast in Vermifilter (VF) and Non-vermifilter (NVF). Most of the organic contaminants were removed by precipitation and adsorption in the voids of the soil or vermicast which served as wastewater filter media (Wang et al., 2010). Typical SEM micrographs of VF and NVF samples, as well as the vermicast sample, are shown in Fig. 1. The NVF sample appeared to have a loose, flaky structure, while the vermicast sample exhibited a distinct physical appearance characterized by a predominantly spherical cell-like structure, which was more compact than in the NVF (Zhao et al., 2010).

The structure of VF sample was more compact than that of the NVF sample, but more loosely arranged than that noted in the vermicast and was looser than that of the control earthworm cast, implying that structure of VF and may be an important constituent of VF. These results confirm that earthworm casts are an important factor that results in higher activities of microbial enzymes in VF compared with NVF. This finding is important because the improved sludge settling characteristics notonly reduce the amount of sludge that needs to be disposed of, but also lead to a decrease in the associated sludge processing costs and environmental burden (Elissen et al., 2006).

Evaluation of vermifiltration process by FT-IR spectroscopy: The type of chemical compound of a material confirms the presence of functional group through FT-IR analysis. The presence or absence of peaks for functional groups of metabolites indicates the degradation of stabilization of the biowaste during the bioconversion process. The infrared spectra were in accordance to the previous studies (Ellerbrock and Kaiser, 2005; Romero et al., 2007; Li et al., 2011). Moreover, the main absorption bands and corresponding assignments are listed in table-4. In general, the FT-IR spectra of DE vermicast from different vermifiltration stages were similar but varied significantly in the relative intensity of absorption bands. With increasing vermicast time, the main changes in FT-IR spectra were summarized as follows:

In the region from 3750 to $3400 \mathrm{~cm}^{-1}$ absorbances are reported to correspond to hydroxyl $(\mathrm{OH})$ stretching vibrations (polysaccharide) and amino groups (Simkovic et al., 2008). Gupta and Garg (2010) have reported that the vermicomposting process reduced in band 3600 to $3100 \mathrm{~cm}^{-1}$ region in FT-IR spectra of vermicomposted cow dung as compared to raw cow dung. Li et al. (2011) and Busato et al. (2012) have reported that vermicomposting process caused the disappearance of easily biodegradable compounds and enhanced the increase of aromatic compounds, which was confirmed by FT-IR analysis. Phenols and Carboxylic group are present $(\mathrm{O}-\mathrm{H}$ stretching at 3500 to $3400 \mathrm{~cm}^{-1}$ ).

The FT-IR spectra of water extracts from the vermicast were similar but significant in the relative intensity of absorption bands. Decrease of the polysaccharides-like substance, protein like, aliphatic compounds and carboxylic groups were observed from the FT-IR after the vermifiltration treatment (Yang et al., 2014). The peak value around 1649 to $1521 \mathrm{~cm}^{-1}$ was found due to be the presence of $\mathrm{C}=\mathrm{C}$ aromatic structure (Karthika et al., 2015). The increase in the aromatic $C$ and aliphatic $C$ ratio is considered as an indicator of an 
increasing degree of organic matter humification in the natural condition of biodegradation (Senesi and Brunetti, 1996) which could be associated with the stability and maturity of compost in their transformation of highly humified substrate (Huag et al., 2006).

The absorbance peak situated from 1490 to 1340 $\mathrm{cm}^{-1}$ might be associated with the bending vibration of aliphatic, $\mathrm{OH}$ deformations, symmetric carboxyl $\left(\mathrm{COO}^{-}\right)$stretch, and stretching of phenolic $\mathrm{OH}$ as compared with the results of Hafidi et al., (2005). A slight broad band around 1095 to 1030 $\mathrm{cm}^{-1}$ related to C-O-C groups in polysaccharides. The sharp band appearing at 850 to $750 \mathrm{~cm}^{-1}$ was related to $\mathrm{C}-\mathrm{O}$ stretching of carbonate and silica as observed from the results of CarrasqueroDuran and Flores (2009), Contreras-Ramos et al., (2004) and Ravindran et al., (2008). However, the intensity of the bands of $1033 \mathrm{~cm}^{-1}$ and $468 \mathrm{~cm}^{-1}$ slightly decreased after effluent treatment and the absorbance of $\mathrm{Si}-\mathrm{O}$ stretching vibrations was characteristic for the $1033 \mathrm{~cm}^{-1}$ region. Those of Si-O bending vibrations are from 475 to $460 \mathrm{~cm}^{-1}$ (Nayak and Singh, 2007).

Furthermore, Fig. 2-7 shows that the organic matter content in the sand was less decomposed or accumulated in VF than in the NVF. The spectral information of these results by Galle et al., (2004) reflects a critical change in the OM quality of the media before and after sewage treatment, which has been consistently observed in river sediments. Certain functional chemical attributes could evaluate the OM contents at the VF media. Thus, the functional group changes probably can explain why the NVF served as the main filter, as well as why NVF played an important role in transforming $\mathrm{C}$ cycle in the earthworm packing bed.

\section{Conclusion}

Vermifiltration technology which uses epigeic earthworms as a means of aerobically treating wastewater is increasingly becoming an ecofriendly wastewater treatment technique. From the above study it is concluded that the polluted wastewater could be treated with an optimal dilution through vermifiltration. The water analyzed after the filtration showed decrease level in BOD, COD and TS by $95 \%, 90 \%$ and $80 \%$ respectively. The vermicast from vermifilter on analysis of parameters such as $\mathrm{TN}, \mathrm{TP}, \mathrm{TK}, \mathrm{TCa}$ and $\mathrm{TMg}$ showed an increased level. The FTIR spectra of DE vermicast were similar but varied in the relative intensity of absorption bands. The increase in the aromatic carbon ratio is considered as an indicator of an increasing degree of organic matter humification, which the stability and maturity of compost their transformation highly humified substrate. Here in this study $25 \%$ dilution was found to be a suitable. Hence vermifiltration is a low cost, odourless and non-labour intensive method of wastewater treatment. In addition, the refuge of such techniques might be easily used in agriculture and in environmental decontamination.

\section{ACKNOWLEDGEMENTS}

The authors are grateful to the Chairman (Mrs. K. Rajeshwari) and Principal (Dr. N. Nagadeepa), Karur Velalar College of Arts and Science for Women, Karur, Tamil Nadu, India, for the encouragement and providing the necessary facilities for the study.

\section{REFERENCES}

1. Abdel-Shafy, H.I. and Mansour, M.S.M. (2018). Solid waste issue: Sources, composition, disposal, recycling, and valorization. Egyptian Journal of Petroleum, 27(4), 1275-1290. https://doi.org/10.1016/ j.ejpe.2018.07.003.

2. Aguilera, M.L. (2003). Purification of wastewater by vermifiltration. Doctoral Thesis. University of Montpellier 2, pp: 188.

3. Aira, M., Monroy, F. and Dominguez, J. (2007). Eisenia fetida (Oligochaeta, Lumbricidae) modifies the structure and physiological capabilities of microbial communities improving carbon mineralization during vermicomposting of pigmanure. Microbial Ecol., 54 (4): 662-671. DOI: 10.1007/s00248-007-9223-4.

4. APHA. 2012. Standard Methods for the Examination of Water and Wastewater. $22^{\text {nd }}$ Edition. Published by the American Public Health Association, American Water and Waterworks Association and Water Environment Federation.

5. Arora, S., Rajpal, A., Bhargava, R., Pruthi, V., Bhatia, A. and Kazmi, A.A. (2014). Antibacterial and enzymatic activity of microbial community during wastewater treatment by pilot scale vermifiltration system. Bioresource Technology, 166: 132-141. DOI:10.1016/j.biortech.2014.05.041.

6. Azuar, S.A. and Ibrahim, M.H. (2012). Comparison of sand and oil palm fibre vermibeds in filtration of palm oil mill effluent (POME). UMT $11^{\text {th }}$ International Annual Symposium on Sustainability Science and Management, $09^{\text {th }}-11^{\text {th }}$ July 2012, Terengganu, Malaysia, 1414-1419.

7. Battacharya, S.S. and Chattopadhyay, G. (2004). Transformation of nitrogen during vermicomposting of flyash. Waste Manage. Res., 22(6): 488-491. DOI:10.1177/0734242X04048625.

8. Busato, G.J., Livia, L.S., Natalia, A.O., Canellas, P.L. and Olivares, L.F. (2012). Changes in labile phosphorus forms during maturation of vermicompost enriched with phosphorus-solubilizing and diazotrophic bacteria. Bioresour. Technol., 110: 390-395. https:// doi.org/10.1016/j.biortech.2012.01.126.

9. Carrasquero-Duran, A. and Flores, I. (2009). Evaluation of lead (II) immobilization by a vermicompost using adsorption isotherms and IR spectroscopy. Bioresour. Technol., 100(4): 1691-1694. https:// doi.org/10.1016/j.biortech.2008.09.013.

10.Chowdhary, P., Yadav, A., Kaithwas, G. and Bharagava, R.N. (2017). Distillery Wastewater: A Major Source of Environmental Pollution and Its Biological Treatment for Environmental Safety. Publisher: Springer: Green Technologies and Environmental Sustainability, pp. 409-435. DOI:10.1007/978-3-319- 
50654-8.

11.Contreras-Ramos, S.M., Alvarez-Bernal, D., TrujilloTapia, N. and Dendooven, L. (2004). Composting of tannery effluent with cow manure and wheat straw. Bioresour. Technol., 94 (2): 223-228. https:// doi.org/10.1016/j.biortech.2003.12.001

12.Cooper, P.F., Job, G.D., Green, M.B. and Shutes, R.B.E. (1996). Reed Beds and Constructed Wetlands for Wastewater Treatment, WRc Publications, Medmenham, Marlow, UK.

13.CPCB, (2018). Central Pollution Control Board. Annual report; 2017-2018.

14.Dominguez, J. (2004). State of the art and new perspectives on vermicomposting research. In: Edwards, CA. (Ed.), Earthworm Ecology, second ed. CRC Press, 401-424.

15.Elissen, H.J.H., Hendrickx, T.L.G., Temmink, H., Buisman, C.J.N., 2006. A new reactor concept for sludge reduction using aquatic worms. Water Res., 40(20): 3713-3718. https://doi.org/10.1016/ j.watres.2006.08.029.

16.Ellerbrock, R.H. and Kaiser, M. (2005). Stability and composition of different soluble soil organic matter fractions - evidence from $\mathrm{d} 13 \mathrm{C}$ and FTIR signatures. Geoderma., 128: 28-37. DOI: 10.1016/ j.geoderma.2004.12.025.

17.Galle, T., Lagen, B.V., Kurtenbach, A. and Bierl, R. (2004). An FTIR-DRIFT study on river sediment particle structure: implications for biofilm dynamic an pollutant binding. Environ. Sci. Technol., 38(17): 44964502. https://doi.org/10.1021/es040005m.

18.Garkal, D.J. and Jadhao, R.K. (2014). A pilot scale study of vermin-biofilter (VBF) for residential quarter wastewater. Inter. J. Curr. Resea. Chem.\& Pharmace. Sci., 1(6): 71-76.

19.Ghatnekar, S.D., Kavin, M.F., Sharma, S.M., Ghatnekar, S.S. and Ghatnekar, A.V. (2010). Application of vermifilter based effluent treatment plant (Pilot scale) for biomanagement of liquid effluents from the gelatine industry. Dynamic soil, Dynamic plant, 4(1): 83-88.

20.Grube, M., Lin, J.G., Lee, P.H. and Kokorevicha, S. (2006). Evaluation of sewage sludge-based compost by FT-IR spectroscopy. Geoderma, 130 (3-4): 324333. https://doi.org/10.1016/j.geoderma.2005.02.005.

21.Gupta, R. and Garg, V.K. (2010). Nutrient recycling of different solid organic wastes employing an epigeic earthworm Eisenia fetida. World Review of Science, Technology Sustainable Development, 7 (3): 239-258. DOI: 10.1504/WRSTSD.2010.032527.

22.Hafidi, M., Amir, S. and Revel, J.C. (2005). Structure characterization of ovlive mill wastewater after aerobic digestion using elemental analysis, FTIR and ${ }^{13} \mathrm{C}$ NMR. Process Biochem., 40(8): 2615-2622. DOI: 10.1016/j.procbio.2004.06.062.

23.He, X., Xi, B., Wei, Z., Guo, X., Li, M., An, D. and Liu, H. (2011). Spectroscopic characterization of water extractable organic matter during composting of municipal solid waste. Chemosphere, 82(4): 541548 j.chemosphere.2010.10.057

24.Huag, G.F., Wu, Q.T., Wong, J.W.C. and Nagar, B.B. (2006). Transformation of organic matter during co composting of pig manure with saw dust. Bioresour. Technol., 97: 1834-1842. https:// doi.org/10.1016/j.biortech.2005.08.024.

25.Jackson, M.L. (1975). Soil Chemical Analysis. Pren- tice Hall of India, New Delhi.

26.Kannadasan, N., Nirmala Natarajan, Anbusaravanan, N., Sekar, P. and Krishnamoorthy, R. (2013). Assessment of sustainable vermiconversion of water hyacinth by Eudrilus eugeniae and Eisenia fetida. Journal of Applied and Natural Science, 5(2): 451-454. https://doi.org/10.31018/jans.v11i2.2024.

27.Karthika, A., Vasanthy, M., Seethdevi, G. and Swabna, V. (2015). Efficacy of vermicomposting for recycling Tectona grandis and Casuarina leaf litter for organic fertilizer production. Indian j. advan. Chemi. Sci., 3(2): 122-127.

28.Kaur, A., Singh, J., Vig, A.P., Dhaliwal, S.S. and Rup, P.J. (2010). Co-composting with and without Eisenia fetida for conversion of toxic paper mill sludge to a soil conditioner. Bioresour. Technol., 101 (21): 8192 8198. DOI: 10.1016/j.biortech.2010.05.041.

29.Kumar, T., Rajpal, A., Bhargava, R. and Prasad, K.S. (2014). Performance evaluation of vermifilter at different hydraulic loading rate using riverbed material. Ecol. Eng., 62: 77-82. http://dx.doi.org/10.1016/ j.ecoleng.2013.10.028.

30.Li, X., Xing, M., Yang, J. and Huang, Z. (2011). Compositional and functional features of humic acid-like fractions from vermicomposting of sewage sludge and cow dung. J. Hazard. Mater., 185: 740-748. https://doi.org/10.1016/j.jhazmat.2010.09.081.

31.Manyuchi, M.M., Phiri, A., Chirinda, N., Muredzi, P., Govha, J. and Sengudzwa, T. (2012). Vermicomposting of Waste Corn Pulp Blended with Cow Dung Manure using Eisenia fetida. World Academy. Sci. Eng. \& Technol., 68: 1306-1309.

32.Nayak, P.S. and Singh, B.K. (2007). Instrumental characterization of clay by XRF, XRD and FTIR. Bull. Mater. Sci., 30(3): 235-238. https://doi.org/10.1007/ s12034-007-0042-5.

33.Olsen, S.R., Cole, C.V., Watanabe, F.S. and Dean, L.A. (1954). Estimation of available phosphorus in soils by extraction with sodium bicarbonate, Circ. US Dept. Agric, pp. 939.

34.Rajpal, A., Bhargava, R., Sasi, S.K. and Chopra, A.K. (2012). On site domestic organic waste treatment through vermitechnology using indigenous earthworm species. Waste Manage. \& Rese., 30(3): 266-275. https://doi.org/10.1177/0734242X11403798.

35.Ravindran, B., Dinesh, S.L., John Kennedy, L. and Sekaran, G. (2008). Vermicomposting of Solid Waste Generated from Leather Industries using epigeic earthworm Eisenia fetida. Appl. Biochem. Biotechnol., 151(2-3): 480-484. DOl:10.1007/s12010-0088222-3.

36.Romero, E., Plaza, C., Senesi, N., Nogales, R. and Polo, A. (2007). Humic acid-like fractions in raw and vermicomposted winery and distillery wastes. Geoderma., 139: 397- 406. https://doi.org/10.1016/ j.geoderma.2007.03.009.

37.Senesi, N. and Brunetti, G. (1996). Chemical and physico-chemical parameters for quality evaluation of humic substances produced during composting. The Science of Composting, Netherlands: Springer, pp: 195-212. https://doi.org/10.1007/978-94-009-15695_20.

38.Senthil Kumar, D., Satheesh Kumar, P., Rajendran, N.M. and Anbuganapathi, G. (2013). Compost maturity assessment using physicochemical, solid-state spectroscopy, and plant bioassay analysis, Journal of Agricultural and Food Chemistry, 61 (47): 11326- 
11331. DOI: $10.1021 / \mathrm{jf} 4034943$.

39.Sharma, M.K. and Kazmi, A.A. (2014). Effect of physical property of supporting media and variable hydraulic loading on hydraulic characteristics of advanced onsite wastewater treatment system. Envir. Technol., 36(11): 1-9.

40.Sharma, M.K., khursheed, A. and Kazmi, A.A. (2014). Modified septic tank-anaerobic filter unit as a two-stage onsite domestic wastewater treatment system. Envirn. Technol., 35: 2183-2193. DOI: 10.1080/09593330.2014.896950.

41.Simard, R.R. (1993). Ammonium acetate extractable elements. In: Martin, R., Carter, S. (Eds.), Soil Sampling and Methods of Analysis, Lewis Publisher, FL, USA, pp. 39-43.

42.Simkovic, I., Dlapa, P., Doerr, S.H., Mataix-Sol-Era, J. and Sasinkova, V. (2008). Thermal destruction of soil water repellency and associated changes to soil organic matters as observed by FTIR spectroscopy. Catena, 74(3): 205-211. DOI: 10.1016/ j.catena.2008.03.003.

43.Sinha, R.K., Bharambe, G. and Chowdhary, U. (2008). Sewage treatment by vermifiltration with synchronous treatment of sludge by earthworms a lowcost sustainable technology over conventional systems with potential for decentralization. The environmentalist, 28: 409-420. https://doi.org/10.1007/ s10669-008-9162-8.

44.Suthar, S. (2008). Bioconversion of post harvest crop residues and cattle shed manure into value-added products using earthworm Eudrilus eugeniae (Kinberg). Ecol. Eng., 32: 206-214. https:// doi.org/10.1016/j.ecoleng.2007.11.002.

45.Suthar, S. (2009). Vermicomposting of vegetablemarket solid waste using Eisenia fetida: impact of bulking material on earthworm growth and decompo- sition rate. Ecol. Eng., 35: 914-920. https:// doi.org/10.1016/j.ecoleng.2008.12.019.

46.Suthar, S. (2010). Pilot-scale vermireactors for sewage sludge stabilization and metal remediation process: Comparison with small-scale vermireactors. Ecol. Eng., 36: 703-712. DOI:10.1016/ j.ecoleng.2009.12.016.

47.Tomar, P. and Suthar, S. (2011). Urban wastewater treatment using vermi-biofiltration system. Desalination, 282: 95-103. DOI:10.1016/j.desal.2011.09.007.

48.Vymazal, J., Brix, H., Cooper, P.F., Haberal, R., Perfler, R. and Laber, J. (1998). Removal mechanisms and types of constructed wetlands, Backhuys Publishers, Leiden, The Netherlands, 17-66.

49.Wang, S., Yang, Y., Lou, S. and Yang, J. (2010). Wastewater treatment performance of a vermifilter enhancement by converter slag-coal cinder filter. Ecol. Eng., 36: 489-494. DOI:10.1016/ j.ecoleng.2009.11.018.

50.Xing, M., Zhao, L., Yang, J., Huang, Z. and Xu, Z. (2011). Distribution and transformation of organic matter during liquid-state vermiconversion of activated sludge using elemental analysis and spectroscopic evaluation. Environ. Eng. Sci., 28: 619-626. DOI: 10.1089/ees.2010.0188.

51.Yang, J., Lv, B., Zhang, J. and Xing, M. (2014). Insight into the roles of earthworm in vermicomposting of sewage sludge by determining the water-extracts through chemical and spectroscopic methods. Bioresour. Technol., 154: 94-100. http://dx.doi.org/10.1 016/j.biortech.2013.12.023.

52.Zhao, L., Wang, Y., Yang, J., Xing, M., Li, X., Yi, D. and Deng, D. (2010). Earthworm-microorganism interactions: A strategy to stabilize domestic wastewater sludge. Water Res., 44: 2572-2582. DOI:10.1016/j.watres.2010.01.011. 